\title{
In vitro studies on antioxidant and free radical scavenging activities of Azima tetracantha. Lam leaf extracts
}

\author{
B. Thendral Hepsibha ${ }^{1}$, S. Sathiya ${ }^{2}$, C. Saravana Babu ${ }^{2}$, V. Premalakshmi ${ }^{3}$ and T. Sekar ${ }^{4}$ \\ ${ }^{1}$ Dept. of Biotechnology, Alpha Arts and Science College, Chennai- 600 116, India. \\ ${ }^{2}$ Centre for Toxicology and Developmental Research, Sri Ramachandra University, Chennai-600 116, India. \\ ${ }^{3}$ Dept. of Horticulture, Agricultural College and Research Institute, Madurai - 625 104, India. \\ ${ }^{4}$ Dept. of Botany, Pachaiyappa's College, Chennai - 600 030, India. \\ thendraljoel@yahoo.com
}

\begin{abstract}
The leaves of Azima tetracantha (Salvadoraceae) commonly known as "mulluchangu" is best known for its medicinal properties. In the present study, the antioxidant potency of successive extracts (petroleum ether, hexane, ethylacetate \& methanol) was investigated, by determining the secondary metabolites such as flavonoids, tannin and phenolic compounds. The free radical scavenging activity of various solvent extracts of the leaves was assessed by using 1, 1diphenyl-2-picrylhydrazyl (DPPH), nitric oxide radical (NO), superoxide anion, hydroxyl radical and lipid peroxide generating models. Reducing power and Vit $\mathrm{E}$ level in the leaves were also measured. The results show that the methanol extract of the plant $A$. tetracantha contains significant quantities of the antioxidant principles compared to the other solvent extracts. Similar observations were seen in scavenging the free radicals by the methanolic extract of the leaves of $A$. tetracantha. Thus the therapeutic property of the leaves of the plant $A$. tetracantha can be attributed to the antioxidant principles which scavenge the free radicals responsible for pathological severity.
\end{abstract}

Keywords: Azima tetracantha, phytochemicals, antioxidants, free radical scavenger.

Introduction

Oxidative stress is a crucial etiological factor to the pathophysiology of a variety of degenerative or pathological conditions such as aging, cancer, coronary heart disease, Alzheimer's disease, atherosclerosis and inflammation (Pong, 2003; Sandhya et al., 2010). Human body has multiple mechanisms especially enzymatic and non enzymatic antioxidant systems to protect the cellular molecules against reactive oxygen species (ROS) induced damage (Anderson, 1999). However due to the overproduction of reactive species and/or inadequate antioxidant defense, it culminates in severe or continued oxidative stress. The harmful action of the free radicals can, however, blocked by antioxidant substances, which scavenge the free radicals and detoxify the organism (Balakumar et al., 2010). Many synthetic antioxidants such as butylated hydroxyl anisole (BHA) and butylated hydroxyl toluene $(\mathrm{BHT})$ are very effective and have been added to food stuffs during food processing but they may possess toxic side effects and also acts as carcinogens (Anagnostopoulou et al., 2006). The safety and toxicity of synthetic antioxidants have been important concerns; therefore, attention has been focussed on the use of natural antioxidants for inhibition or protection from oxidative damage (Howell,1986). In recent years attention has been directed in utilizing natural antioxidants substantially (Shahidi et al., 2006; Vetrivel Rajan \& Shanmugavalli, 2009). Secondary metabolites of plants such as flavonoids, anthocyanins, carotenoids and vitamins have been reported as promising antioxidants (Kivits et al., 1997). Plant-derived antioxidants function as singlet and triplet oxygen quenchers, peroxide decomposers and/or chelators of the catalytic metal ions (Robak \& Marcinkiewiez, 1995).

Traditionally herbal medicines are currently used in protecting and restoring health. People of all continents and civilizations used plants in one form or the other. Azima tetracantha Lam., (Salvadoraceae) commonly known as "mulluchangu" is a glabrous, rigid, rambling, thorny shrub commonly called Bee sting bush found in Africa, India, and Madagascar. Several medicinal properties are attributed to this plant in the Indian system of medicine and included in the check list of traded medicinal plants. The ethno botanical survey reveals the usage of this plant as an unique folk medicine by the adivasis (tribal) (Hebbar et al., 2004; Mohamed Al-Fatimi et al., 2007; Murthy et al., 2008; Vikneshwaran et al., 2008; Raghupathy et al., 2008; Ignacimuthu et al., 2008). The root, root bark and leaves are administered with food as a remedy for rheumatism (Chopra et al., 1956; Kirtikar et al., 1984). It is a powerful diuretic given in rheumatism, dropsy, dyspepsia and chronic diarrhea and as a stimulant tonic after confinement (Nadkarni, 1976). The leaves are found to contain azimine, azcarpine, carpine and isorhamnitine-3-O-rutinoside etc., (Rall et al., 1967; Williams \& Nagarajan, 1988, Bennet et al., 2004). Friedelin, lupeol, glutinol and $\beta$-sitosterol were isolated from the petroleum ether extract of the leaves of $A$.
Research article

CIndian Society for Education and Environment (iSee)
"Herbal antioxidant" http://www.indjst.org
Thendral et al. Indian J.Sci.Technol. 
tetracantha (Rao \& Prasada Rao, 1978). The seeds of this plant have been found to possess novel fatty acids along with other fatty acids (Daulatabad et al., 1991). Antimicrobial activity was also reported for this plant (Siva et al., 2008). A. tetracantha leaf powder was assessed for its anti-inflammatory activity (Ismail et al., 1997). The benzene, chloroform and aqueous extract of leaves of $A$. tetracantha were screened for analgesic activity in mice using hot plate method (Nandgude et al., 2007). The ethanolic leaf extract of Azima tetracantha Lam. was investigated for hypoglycemic and hypolipidemic activity in alloxan-induced diabetic albino rats (Begum et al., 2009). However, information pertaining to the systematic studies on the antioxidant properties of $A$. tetracantha is lacking. In view of the above fact, in the present study the possible antioxidant activity of the various solvent extracts petroleum ether, hexane, ethylacetate and methanol were investigated by employing different in vitro free radical scavenging models.

\section{Materials and methods}

\section{Plant collection and extraction}

The fresh leaves of $A$. tetracantha were collected during the month of September from the foothill of Sirumalai Hills, Dindugal, Tamil Nadu, India. Botanical identification was performed by Dr. T. Sekar, Dept. of Botany, Pachaiyappas's College where the voucher specimen has been deposited. The leaves were washed in fresh water to remove adhering dust and then dried under shade. The air dried and powdered leaves were extracted in soxhlet extractor successively with petroleum ether, hexane, ethyl acetate and methanol. The successive extracts were evaporated to dryness and then stored residue was used for analysis.

\section{Methods}

Preliminary phytochemical screening of the four successive extracts (Petroleum ether, hexane, ethylacetate \& methanol) were performed (Kokate, 2001).The flavonoid content of the extracts was measured using colorimetric assay as described by Chang et al., 2002. The amount of tannins in the extracts was determined using Folin-Ciocalteau reagent according to the Schanderl (1970) procedure. The level of total phenolic compounds in the extracts were determined by Folin-Ciocalteu reagent using gallic acid as the standard (McDonald et al., 2001). Total Vitamin E content was measured according to the method of Prieto et al. (1999). The reductive potential of the extracts were determined according to the method of Oyaizu (1986).

Lipid peroxidation inhibitory capacity was assayed in rat liver homogenate according to the method adopted by Ohkawa et al., 1979. The free radical scavenging activity of the four extracts were measured in vitro by 1, 1diphenyl-2-picryl-hydrazyl (DPPH) assay by the method of Koleva et al. (2002). The influence of extracts on the generation of nitric oxide was measured according to the method described by Green et al. (1982). The ability of extracts to scavenge superoxide radicals was measured by the method of Kakkar et al. (1984). Hydroxy radical scavenging activity was performed as described by Halliwell et al. (1987).

Statistical analysis

Experimental results were expressed as mean \pm SEM of three parallel measurements.

Results and discussion

Phytochemical analysis

The phytochemical results confirms the presence of alkaloids, phenolic compounds, reducing sugars, flavonoids, tannins and glycosides in all the four successive extracts but in variable quantities (Table 1).These are the phytochemicals which are essential in many medicinal plants responsible for the antioxidant property either by scavenging free radicals or by preventing their formation (Patricia et al., 2005). The reported medicinal property of the plant might be due to the presence of these bioactive components in $A$. tetracantha. Phytochemical such as steroids, saponins, quinones and anthroquinones were found to be absent in all the four test extracts.

\section{Effect on lipid peroxidation}

Lipid peroxidation, a process induced by free radicals, leads to oxidative deterioration of polyunsaturated lipids and also damages the biomolecules. Transition metal ions, such as iron and copper, are known to stimulate LPO through various mechanisms (Halliwell \& Gutteridge, 1984). These metal ions may generate hydroxyl radicals to initiate the lipid peroxidation process and/or propagate the chain process via decomposition of lipid hydro peroxides (Braughler et al., 1987). In this investigation the lipid peroxidation of rat liver homogenate was triggered by Fe (II)-ascorbate, and the end products of the process were measured in terms of thiobarbituric acid-reactive substances (TBARS) formed. All the extracts significantly inhibited the lipid peroxidation. Maximum inhibition was observed with methanol extract $\left(\mathrm{IC}_{50} 99.53 \pm 6.17 \mu \mathrm{g} / \mathrm{ml}\right)$ followed by the ethyl acetate $\left(\mathrm{IC}_{50} 119.05 \pm 2.05 \mu \mathrm{g} / \mathrm{ml}\right)$, petroleum ether $\left(\mathrm{IC}_{50} 1430.5 \pm 44.5 \mu \mathrm{g} / \mathrm{ml}\right)$ and hexane extracts $\left(\mathrm{IC}_{50} 1538.5 \pm 19.5 \mu \mathrm{g} / \mathrm{ml}\right)(\mathrm{Fig} 1)$. The scavenging effect was comparable to that of the standard ascorbic acid with $\mathrm{IC}_{50}$ value of $76.75 \pm 1.36 \mu \mathrm{g} / \mathrm{ml}$. From the study it was evident that ability of the extract to inhibit lipid peroxide level may be due to the chelation of $\mathrm{Fe}^{2+}$ or trapping of free radical or chain breaking nature of the extract.

\section{Effect on scavenging DPPH radical}

The DPPH assay method is based on the reduction of $\mathrm{DPPH}$, a stable free radical. The free radical DPPH with an odd electron gives a maximum absorption at $517 \mathrm{~nm}$ (purple colour). As the odd electron of the radical becomes paired off in the presence of a hydrogen donor, e.g., a free radical-scavenging antioxidant, the absorption strength is decreased and results in decolorization (yellow colour) with respect to the number of electrons captured (Blois, 1958). More the decolorization more is the reducing ability. This test has been the most accepted 
Fig. 1. Inhibition of lipid peroxidation

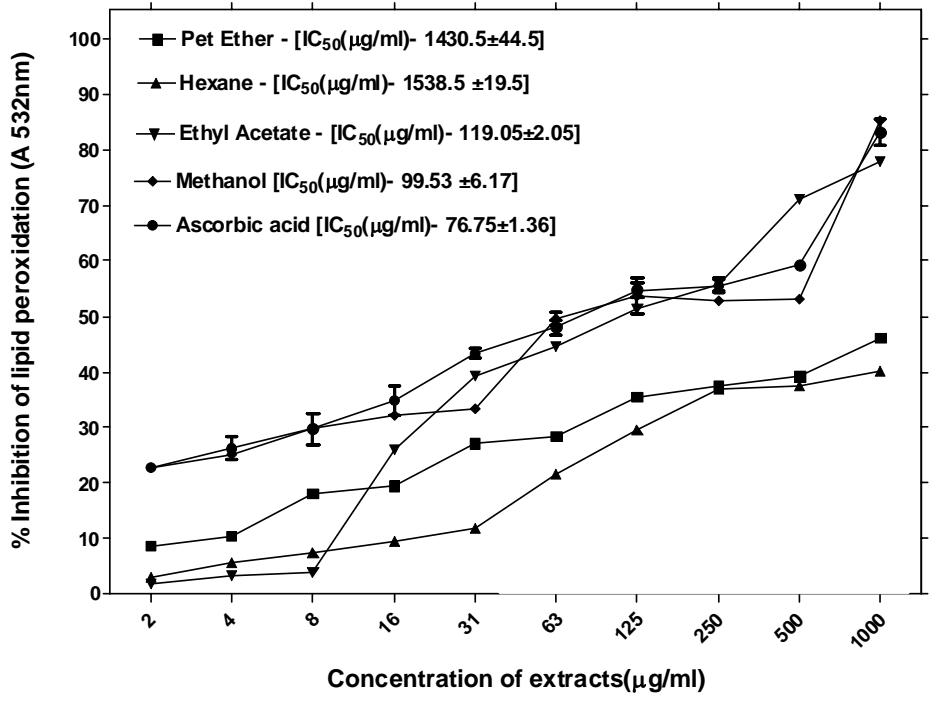

Fig. 3. Nitric oxide scavenging activity

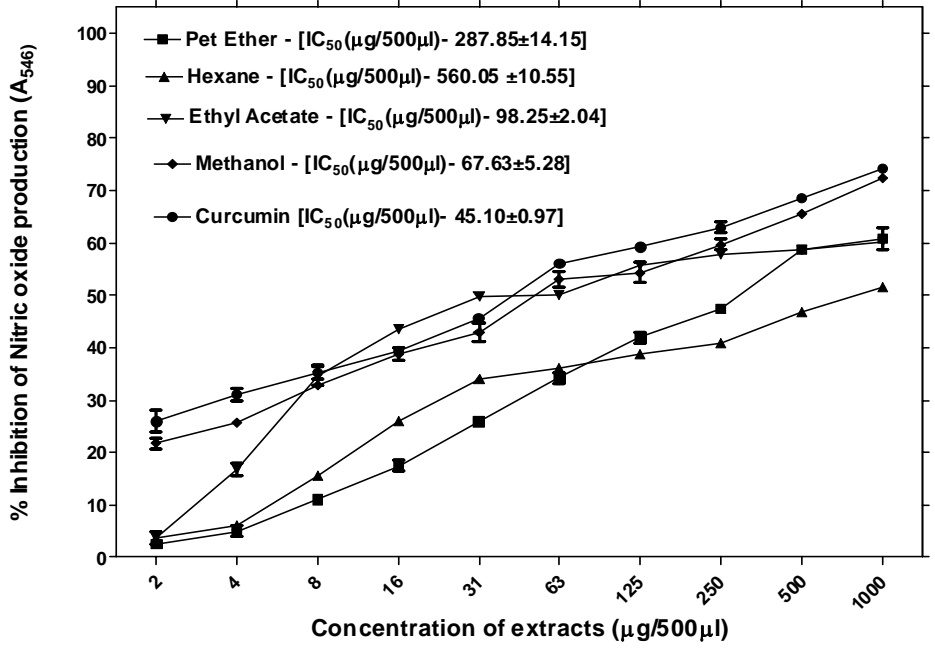

Vol. 3 No. 5 (May 2010)

ISSN: 0974- 6846

Fig. 2. Scavenging of DPPH radical

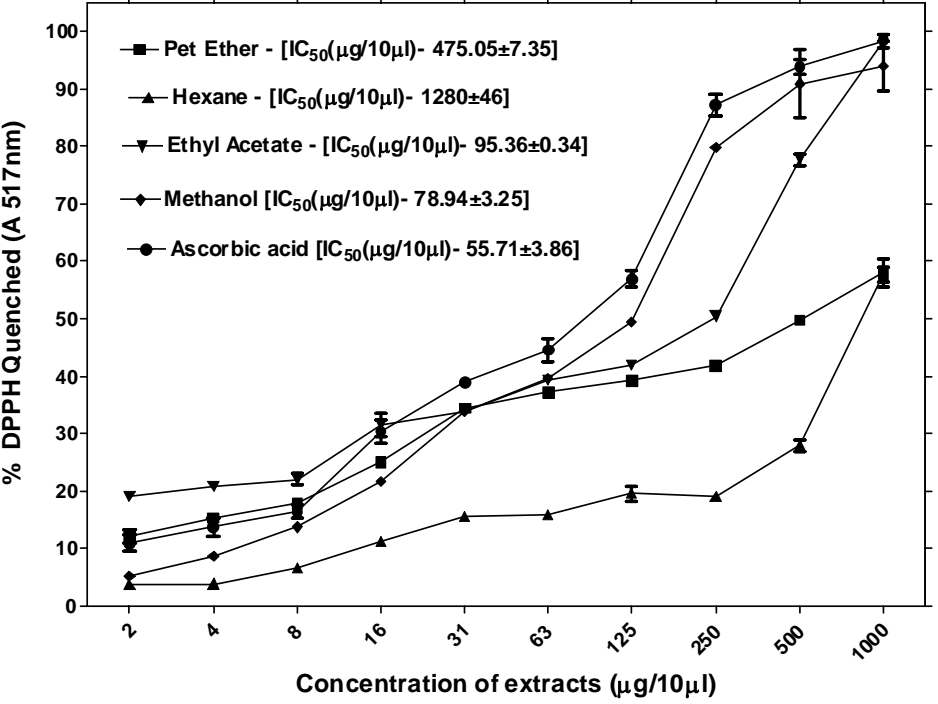

Fig. 4. Inhibition of superoxide anion

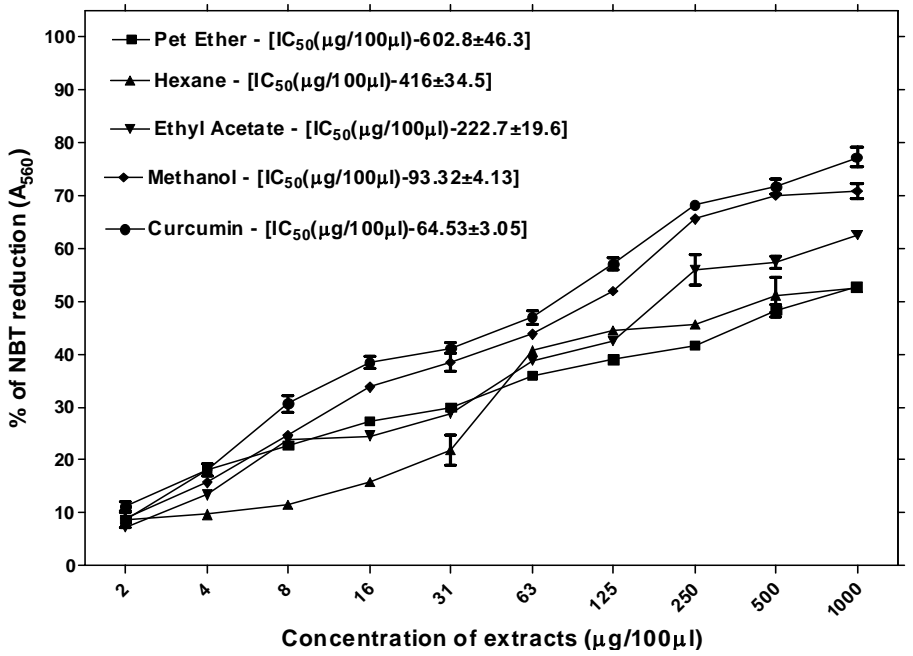

Fig.5. Scavenging of hydroxyl radical

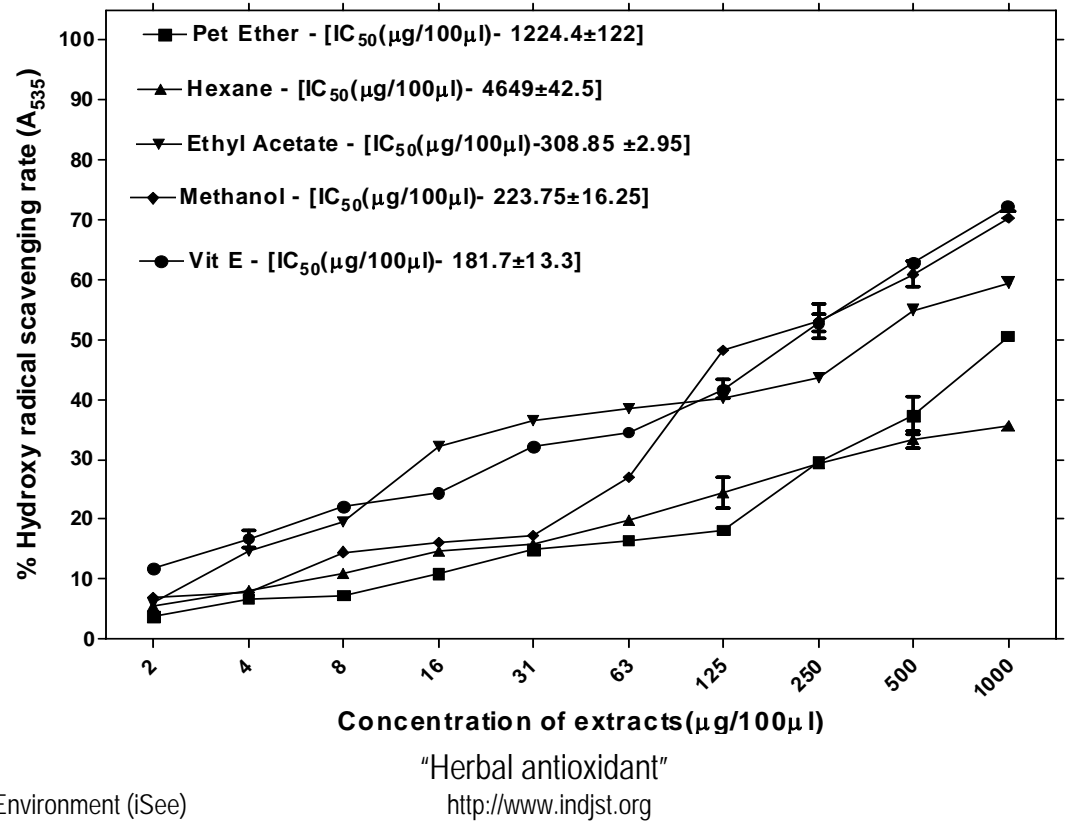

Thendral et al.

Research article

CIndian Society for Education and Environment (iSee)
"Herbal antioxidant"

itt://www.indjst.org 
model for evaluating the free radical scavenging activity of any new drug. The percent DPPH scavenging activities of $A$. tetracantha extracts were summarised in (Fig. 2). At all concentrations tested, $A$. tetracantha exhibited a dosedependent DPPH radical-scavenging activity. The order of the scavenging activity was found to be methanol $\left(\mathrm{IC}_{50}\right.$ $78.94 \pm 3.25 \mu \mathrm{g} / 10 \mu \mathrm{l})>$ ethyl acetate $\left(\mathrm{IC}_{50} 95.36 \pm 0.34\right.$ $\mu \mathrm{g} / 10 \mu \mathrm{l})>$ petroleum ether $\left(\mathrm{IC}_{50} 475.05 \pm 7.35 \mu \mathrm{g} / 10 \mu \mathrm{l}\right)>$ Hexane $\left(\mathrm{IC}_{50} 1280 \pm 46 \mu \mathrm{g} / 10 \mu \mathrm{l}\right)$. The scavenging effect was comparable to that of the standard ascorbic acid with $I_{50}$ value of $55.71 \pm 3.86 \mu \mathrm{g} / 10 \mu \mathrm{l}$. The results suggested that the medicinal property exhibited by the plant might be due to the radical scavenging activity. Our results are in tune with earlier investigations that the methanol extracts of Pterocarpus santalinus exhibited significant DPPH radical inhibition (Arokiyaraj et al., 2008).

Inhibition of NO radical production

Nitric oxide (NO) has also been involved in a variety of biological functions, including neurotransmission, vascular homeostasis, antimicrobial, and antitumor activities (Nathan \& Hibbs, 1991). Despite the possible beneficial effects of $\mathrm{NO}$; its contribution to oxidative damage is also reported. This is due to the fact that NO can react with superoxide to form the peroxynitrite anion, which is a potential oxidant that can decompose to produce $\mathrm{OH}^{-}$and NO (Pacher et al., 2007). Large amounts of NO may lead to tissue damage. It would be interesting to develop potent and selective inhibitors of NO for potential therapeutic use (Nowakowska, 2007). The ability to scavenge $50 \%$ of NO radical was found to be $\mathrm{IC}_{50} 67.63 \pm 5.28 \mu \mathrm{g} / 500 \mu \mathrm{l}$ for methanol $>$ ethyl acetate $\left(\mathrm{IC}_{50} 98.25 \pm 2.04 \mu \mathrm{g} / 500 \mu \mathrm{l}\right)>$ petroleum ether $\left(\mathrm{IC}_{50} 287.85 \pm 14.15 \mu \mathrm{g} / 500 \mu \mathrm{l}\right) \quad>$ hexane $\left(\mathrm{IC}_{50}\right.$ $560.05 \pm 10.55 \mu \mathrm{g} / 500 \mu \mathrm{l}$ ) (Fig. 3). The scavenging effect was comparable to that of the standard curcumin with $\mathrm{IC}_{50}$ value of $45.1 \pm 0.97 \mu \mathrm{g} / 500 \mu \mathrm{l}$. So it could be presumed that the methanol extract could act as a potential therapeutic agent for the control of oxidative damage.

Inhibition of superoxide anion radical production

Superoxide is biologically important as it can form singlet oxygen and hydroxyl radical (Korycka-Dahl \& Richardson, 1978). Overproduction of superoxide anion radical, contributes to redox imbalance and associated with harmful physiological consequences (Pervaiz \& Clement, 2007). Superoxide anion are generated in PMS$\mathrm{NADH}$ system by the oxidation of NADH and assayed by the reduction of NBT resulting in the formation of blue formazan. From the present study it was found that the inhibition was seen in a dose dependent manner (Fig. 4). Extracts found to possess the activity in the order of their scavenging effect methanol $\left(\mathrm{IC}_{50} 93.32 \pm 4.13 \mu \mathrm{g} / 100 \mu \mathrm{l}\right)>$ ethyl acetate $\left(\mathrm{IC}_{50} 222.7 \pm 19.6 \mu \mathrm{g} / 100 \mu \mathrm{l}\right)>$ hexane $\left(\mathrm{IC}_{50}\right.$ $416 \pm 34.5 \mu \mathrm{g} / 100 \mu \mathrm{l})>$ petroleum ether $\left(\mathrm{IC}_{50} 602.8 \pm 46.3\right.$ $\mu \mathrm{g} / 100 \mu \mathrm{l})$. The scavenging effect was comparable to that of the standard curcumin with $\mathrm{IC}_{50}$ value of $64.53 \pm 3.05$ $\mu \mathrm{g} / 100 \mu \mathrm{l}$. The antioxidant activity is afforded, not only by phenolic compounds, but also has important contributions from other superoxide anion radical scavengers, such as essential oils, carotenoids and vitamins (Moure et al., 2001).

\section{Scavenging effect on hydroxy radical}

Hydroxy radical is a highly reactive radical formed in biological systems and capable of damaging almost every molecule found in living cells (Halliwell,1991). This radical has the capacity to induce carcinogenesis, mutagenesis and rapidly initiates lipid peroxidation (Rajesh Manian et al., 2008). In vitro, $\left(\mathrm{OH}^{-}\right)$were generated by a mixture of $\mathrm{Fe}^{3+}$-EDTA, $\mathrm{H}_{2} \mathrm{O}_{2}$ and ascorbic acid and were assessed by monitoring the degraded fragments of deoxyribose, through malonaldehyde (MDA) formation .If any drug scavenges the hydroxyl radical, they may either scavenge the radical or may chelate the $\mathrm{Fe}^{2+}$ ion making them unavailable for the Fentons reaction. Here the successive extracts were tested, where they found to exhibit a dose dependent hydroxyl radical scavenging activity (Fig. 5). The hexane extract was found to exhibit the scavenging activity with $\mathrm{IC}_{50} 4649 \pm 42.5 \mu \mathrm{g} / 100 \mu \mathrm{l}$, followed by petroleum ether extract $\left(\mathrm{IC}_{50} \quad 1224 \pm 122\right.$ $\mu \mathrm{g} / 100 \mu \mathrm{l})$, ethyl acetate $\left(\mathrm{IC}_{50} 308.85 \pm 2.95 \mu \mathrm{g} / 100 \mu \mathrm{l}\right)$ and the methanol extract with the highest scavenging activity $\left(\mathrm{IC}_{50} 223.75 \pm 16.25 \mu \mathrm{g} / 100 \mu \mathrm{l}\right)$. The scavenging effect was comparable to that of the standard Vitamin $\mathrm{E}$ with $\mathrm{IC}_{50}$ value of $181.7 \pm 13.3 \mu \mathrm{g} / 100 \mu \mathrm{l}$. The radical scavenging power of the extracts can be accounted by the presence of flavonoid, tannin, phenols and vitamins. Plant extracts containing polyphenols are reported to quench oxygenderived free radicals by donating a hydrogen atom or an electron to the free radical (Mi-Yae Shon et al., 2003) or neutralize free radicals or by their chelating ability due to their high nucleophilic character of the aromatic ring (Becana \& Klucas, 1992).

\section{Bioactive antioxidant levels:}

Flavonoids are a group of effective antioxidants which are present abundantly throughout the plant kingdom. Flavonoid and related compound are effective in scavenging DPPH radical (Apati et al., 2003), hydroxyl radical and in metal-chelating capacity (Lean et al., 1999). Flavonoids are found to exhibit numerous biological activities like vasodilatory, anticarcinogenic, antiinflammatory, antibacterial, immune-stimulating, antiallergic, and antiviral effects (Middleton \& Kandaswami, 1992). In the present study the methanol extract was found to possess significant amount, $40 \mathrm{mg} / \mathrm{gm}$ when compared to other extracts (Table 1).

Tannins, the high molecular weight phenols, act as a good scavenger of free radical either by donating hydrogen atom or by reducing them. This property is attributed by the molecular weight, the number of aromatic rings and nature of hydroxyl group's substitution and specific functional groups present in the tannins (Hagerman et al., 1998). The results show that the methanol extract contains more tannin content when compared to the other extracts (Table 2). Thus polar
Research article

CIndian Society for Education and Environment (iSee)
"Herbal antioxidant" http://www.indjst.org
Thendral et al. Indian J.Sci.Technol. 
fraction may have more polyhydroxy phenolics such as tannins, which may be acting synergistically, with other phytoconstituents to exhibit its antioxidant property.

Table 1. preliminary phytochemical analysis of Azima tetracantha leaf extracts

\begin{tabular}{|l|c|c|c|c|}
\hline Phytoconstituents & $\begin{array}{c}\text { Pet. } \\
\text { ether }\end{array}$ & $\begin{array}{c}\mathrm{n}- \\
\text { Hexane }\end{array}$ & Ethylacetae & Methanol \\
\hline Steroids & - & - & - & - \\
\hline Alkaloids & +++ & +++ & +++ & +++ \\
\hline $\begin{array}{l}\text { Phenolic } \\
\text { Compounds }\end{array}$ & ++ & ++ & ++ & +++ \\
\hline Reducing sugars & + & + & + & + \\
\hline Flavonoids & + & + & + & ++ \\
\hline Tannins & ++ & ++ & ++ & ++ \\
\hline Glycosides & - & + & - & +++ \\
\hline Saponins & - & - & - & - \\
\hline Anthraquinones & - & - & - & - \\
\hline Quinones & - & - & - & - \\
\hline Proteins & + & + & ++ & ++ \\
\hline \multicolumn{2}{|r|}{ - mild $;++$} & moderate ; +++ - more
\end{tabular}

Table 2. Comparison of extraction yield, flavonoid content, tannin content and total phenolic content of different successive extracts obtained from leaves of Azima tetracantha

\begin{tabular}{|c|c|c|c|c|}
\hline Extracts & $\begin{array}{c}\text { Yield }^{\mathrm{a}} \\
(\% \mathrm{w} / \mathrm{w})\end{array}$ & $\begin{array}{c}\text { Flavonoid }^{\mathrm{a}} \\
(\mathrm{mg} / \mathrm{gm} \\
\text { extract) }\end{array}$ & $\begin{array}{c}\text { Tannin }^{\mathrm{a}} \\
\text { (mg/gm }_{\text {extract) }}\end{array}$ & $\begin{array}{c}\text { Total } \\
\text { phenolic } \\
\text { compounds } \\
\text { (mg/gm } \\
\text { extract) }\end{array}$ \\
\hline $\begin{array}{c}\text { Petroleum } \\
\text { Ether }\end{array}$ & 1.50 & $15.47 \pm 0.40$ & $2.70 \pm 0.10$ & $33.08 \pm 0.09$ \\
\hline n- Hexane & 0.280 & $5.48 \pm 0.28$ & $0.84 \pm 0.06$ & $46.53 \pm 1.34$ \\
\hline $\begin{array}{c}\text { Ethyl } \\
\text { Acetate }\end{array}$ & 1.97 & $33.54 \pm 0.12$ & $35.18 \pm 0.69$ & $66.19 \pm 3.41$ \\
\hline Methanol & 27.17 & $40.01 \pm 0.06$ & $41.24 \pm 0.10$ & $84.25 \pm 2.41$ \\
\hline \multicolumn{4}{|c|}{ Each value is expressed as mean \pm SEM (n=3). }
\end{tabular}

Phenols are very important plant constituents because of their radical scavenging ability due to the hydroxyl groups (Hatano et al., 1989).The total phenolic content of the four successive extracts were quantified with Folin Ciocalteau reagent. The phenolic content of the successive extracts are shown in Table 2. The phenolic content of methanolic extract was found to be high followed by ethylacetate, hexane and petroleum ether extracts. This observation suggests that the phytochemicals necessary for the antioxidant and radical Table 3. Reducing capacity and vitamin E content of Azima tetracantha extracts

\begin{tabular}{|c|c|c|}
\hline Extracts & $\begin{array}{c}\text { Reducing capacity } \\
\text { Rexts } \\
\text { (gm extract which }_{\text {contains } 1 \mathrm{gm}} \\
\text { equivalent of Vit C) }\end{array}$ & $\begin{array}{c}\text { Vit E Content } \\
\text { (gm extract which } \\
\text { contains } 1 \mathrm{gm} \\
\text { equivalent of Vit E) }\end{array}$ \\
\hline $\begin{array}{c}\text { Petroleum } \\
\text { Ether }\end{array}$ & $51.41 \pm 0.84$ & $10.29 \pm 0.14$ \\
\hline $\mathrm{n}$ - Hexane & $41.19 \pm 2.3$ & $19.48 \pm 0.38$ \\
\hline Ethyl Acetate & $27.57 \pm 0.28$ & $14.96 \pm 0.09$ \\
\hline Methanol & $17.19 \pm 0.39$ & $11.11 \pm 0.17$ \\
\hline
\end{tabular}

${ }^{a}$ Mean of triplicate determinations \pm SEM $(n=3) .{ }^{b}$ Mean of triplicate determinations $\pm \operatorname{SEM}(n=3)$ (Bito et al., 2000).

Conclusion scavenging activity are

high phenolic content. Polyphenols are known to exhibit a variety of biological actions such as free radicals scavenging, metal chelation, modulation of enzyme activity and more recently to effect signal transduction, activation of transcription factors and gene expression

Ascorbic acid is a very good reducing agent and free radical scavenger. It is also reported to prevent the damage to RBC membranes by interacting with superoxide and hydroxy radical in plasma, and also by influencing $\alpha$-tocopherol in inhibition of LPO by recycling the tocopherol radical (Beyer,1994). Interestingly the ascorbic acid content of $A$. tetracantha extracts was found to be in the order methanol extract $>$ ethyl acetate $>$ hexane $>$ petroleum ether. a-tocopherol could also directly react with a variety of oxy radicals, including the peroxy radical, $\mathrm{OH}^{-}, \mathrm{O}^{2-}$ and singlet oxygen (Littarru et al., 1984). Our study reveals the order of a-tocopherol content of the extracts as follows petroleum ether $>$ methanol > ethyl acetate > hexane. So the vitamins $\mathrm{E}$ and $\mathrm{C}$ present in $A$. tetracantha leaves are quenchers of free radicals and good reducing agents (Table 3 ). Thus the results confirm that $A$. tetracantha could be an important source of natural antioxidants.

Results of this study show that $A$. tetracantha leaves are good source of natural phenolic compounds. The methanolic extract of the $A$. tetracantha leaves showed better free radical capacity against different reactive oxygen /nitrogen species, among other extracts although with different efficiencies. The high content of antioxidants like phenolic compounds, flavonoids and vitamins found in these extracts, may impart health benefits by combating the free radicals in synergistic manner along with other compounds and thus constitute part of the basis for the ethno pharmacological claim. Thus $A$. tetracantha shall further be subjected to systematic in vivo studies for the preventive action against cancer, cardiovascular and neurological disorders.

Acknowledgement

Thendral Hepsibha, acknowledges Mother Teresa Women's Univ. for opportunity given to do the work and thanks Dr. A. present abundantly in the polar fraction than the non polar fractions. This might be the reason for the methanolic extract to possess more phenol content when compared to other extracts. The pronounced antioxidant activity of the extract of $A$. tetracantha, manifested as inhibition of lipid peroxidation (LPO), scavenging of hydroxyl, nitric oxide and superoxide radicals, was possibly due to its
Geetha, Associate Professor in Biochemistry, Bharathi Women's College, for her constant encouragement and help throughout the research work.

\section{References}

1. Anagnostopoulou MA, Kefalas P, Papageorgiou VP, Assimepoulou AN and Boskou D (2006) Radical scavenging activity of various extracts and fractions of
Research article

CIndian Society for Education and Environment (iSee)
"Herbal antioxidant" http://www.indjst.org
Thendral et al. Indian J.Sci.Technol. 
sweet orange peel (Citrus sinensis). Food Chem. 94, 1925.

2. Anderson D (1999) Antioxidant defences against reactive oxygen species causing genetic and other damage. Mutation Res. 350, 103-108.

3. Apati P, Szentmihalyi K, Kristo Sz T, Papp I, Vinkler P, Szoke E (2003) Herbal remedies of Solidago, correlation of phytochemical characteristics and antioxidative properties. J. Pharmacol. Biomed. Analysis. 32, 10451053.

4. Arokiyaraj S, Radha R, Martin S and Perinbam K (2008) Phytochemical analysis and anti-diabetic activity of Cadaba fruticosa R.Br. Indian J.Sci.Technol. 1 (6), 1-4. Domain site: http://www.indjst.org.

5. Balakumar K, Ramanathan S Kumaresan and Suresh R (2010) DNA damage by sodium arsenite in experimental rats: ameliorative effects of antioxidant vitamins $\mathrm{C}$ and $\mathrm{E}$. Indian J.Sci.Technol. 3 (3), 322-327. Domain site: http://www.indjst.org.

6. Becana M and Klucas RV (1992) Transition metals in legume root nodules; iron-dependent free radical production increases during nodule senescence. Proc. Nat. Academy Sci. USA, 89, 8958-8962.

7. Begum TN, Muhammad llyas $\mathrm{MH}$, Burkanudeen $\mathrm{A}$, Kalavathy S, Vijaya Anand A, Sampathkumar P and Jaswanth (2009) A Hypoglycemic and antihyperlipidemic activity of ethanolic leaf extract of Azima tetracantha Lam. on alloxan-induced diabetic rats. J. Cell Tissue Res. 9(1), 1681-1685.

8. Bennett RN, Rosa EA, Perkins L and Kroon PA (2004) Profiling glucosinolates, flavonoids, alkaloids, and other secondary metabolites in tissues of Azima tetracantha L (Salvadoraceae). J. Agric. Food Chem. 52(19), 58565862.

9. Beyer RE (1994) The role of ascorbate in antioxidant protection of biomembranes: Interaction with vitamin $\mathrm{E}$ and coenzyme Q. J. Bioenergy Biomembrane. 26, 349-358.

10. Bito T, Roy S, Sen CK and Packer L (2000) Pine bark extract Pycnogenol down regulates IFN-g-induced adhesion of $T$ cells to human keratinocytes by inhibiting inducible ICAM-1 expression. Free Radical Biol. Med. 28, 219-227.

11. Blois MS (1958) Antioxidant determinations by the use of a stable free radical. Nature. 181, 1199-1200.

12. Braughler JM, Chase RL and Pregenzer JF (1987) Oxidation of ferrous ion during peroxidation of various lipid substrates. Biochem. Biophy. Acta. 921, 457-464.

13. Chang C, Yang M, Wen H and Chern J (2002) Estimation of total flavonoid content in propolis by two complementary colorimetric methods. J. Food Drug Analysis. 10, 178-182.

14. Chopra RN, Nayar SL and Chopra C (1956) Glossary of Indian Medicinal Plants. CSIR, New Delhi, pp32, 218.

15. Daulatabad CD, Desai VA, Hosamani KM and Jawkhande AM (1991) Novel fatty acids in Azima tetracantha seed oil. J. Amer. Oil Chemists Soc. 68, 978979.
Vol. 3 No. 5 (May 2010)

ISSN: 0974- 6846

16. Green LC, Wagner DA, Glogowski J, Skipper PL, Wishnok JS and Tannenbaum SR (1982) Analysis of nitrate and in biological fluids. Anal.Biochem. 126, 131.

17. Hagerman AE, Riedl KM, Jones GA, Sovik KN, Ritchard NT and Hartzfeld PW (1998) High molecular weight plant polyphenolics (Tannins) as biological antioxidants. J. Agri. Food Chem. 46, 1887-1892.

18. Halliwell B (1991) Reactive oxygen species in living systems: source, biochemistry and role in human disease. Annl. J. Med. 91(Suppl. 3C), 14S-22S.

19. Halliwell B and Gutteridge JMC (1984) Oxygen toxicity, oxygen radicals, transition metals and disease. Biochem. J. 219, 1-14.

20. Halliwell B, Gutteridge JMC and Aruoma OI (1987) The deoxyribose method: simple "test-tube" assay for determination of rate constants for reactions of hydroxyl radicals. Anal. Biochem. 165, 215-219.

21. Hatano T, Edamatsu R, Mori A, Fujita and Yasuhara E (1989) Effect of interaction of tannins with co-existing substances VI. Effect of tannins and related polyphenols on superoxide anion radical and on DPPH radical. Chem. Pharma. Bull. 37, 2016-2021.

22. Hebbar SS, Harsha VH, Shripathi V, Hegde VR (2004) Ethnomedicine of Dharwad district in Karnataka, Indiaplants used in oral health care. J. of Ethnopharmacol. 94, 261-266.

23. Howell JC (1986) Food antioxidants: international perspectives welcome and introductory remarks. Food Chem. Toxicol. 24, 997.

24. Ignacimuthu SM, Ayyanar AK, Sankarasivaraman (2008) Ethnobotanical study of medicinal plants used by Paliyar tribals in Theni district of Tamil Nadu, India. Fitoterapia. 79, 562-568.

25. Ismail TS, Gopalakrishnan S, Begum VH and Elango V (1997) Anti-inflammatory activity of Salacia oblonga Wall and Azima tetracantha Lam. J. Ethnopharmacol. 56(2), 145-152.

26. Kakkar P, Das B and Viswanathan PN (1984) A modified spectrophotometric assay of superoxide dismutase. Ind. J. Biochem. Biophys, 21, 130-32.

27. Kirtikar KR, Basu BD and An ICS (1984) Ind. Med. Plants. $1 \& 2,2^{\text {nd }}$ Edn. Bishen Singh Mahendra Pal Singh, Dehra Dun. pp: 582, 1541.

28. Kivits GAA, Vam der Sman FJP, Tijburg LBM (1997) Analysis of catechin from green and black tea in humans: a specific and sensitive colorimetric assay of total catechins in biological fluids. Int. J. Food Sci. Nutr. 48, 387-392.

29. Kokate CK (2001) Parmacohnosy. 16 ${ }^{\text {th }}$ edn., Nirali Prakasham, Mumbai, India.

30. Koleva II, Van Beek TA, Linssen JPH, de Groot A and Evstatieva LN (2002) Screening of plant extracts for antioxidant activity: a comparative study on three testing methods. Phytochem. Analysis. 13, 8-17.

31. Korycka-Dahl M and Richardson M (1978) Photogeneration of superoxide anion in serum of bovine milk and in model systems containing riboflavin and aminoacids. J. Dairy Sci. 61, 400-407.

32. Lean M, Norrozi M, Kelly L, Burrns J, Talwar D and Satter N (1999) Dietary flavanoids protect diabetic human
Research article

CIndian Society for Education and Environment (iSee)
"Herbal antioxidant"

http://www.indjst.org
Thendral et al. Indian J.Sci.Technol. 
lymphocytes against oxidant damage to DNA. Diabetes. 48, 176-181.

33. Littarru GP, Lippa S, De Sole P, Oradei A, Dalla Torre F and Mari M (1984) Quenching of singlet oxygen by Dalphatocopherol in human granulocytes. Biochem. Biophy. Res. Comm. 119, 1056-1061.

34. McDonald S, Prenzler PD, Autolovich M and Robards K (2001) Phenolic content and antioxidant activity of olive extracts. Food Chem. 73, 73-84.

35. Middleton E and Kandaswami C (1992) Efects of flavonoids on immune and inflammatory function. Biochem. Pharmacol. 43, 1167-1179.

36. Mi-Yae Shon, Tae-Hun Kim and Nak-Ju Sung (2003) Antioxidants and free radical scavenging activity of Phellinus baumii (Phellinus of Hymenochaetaceae) extracts. Food Chem. 82, 593-597.

37. Mohamed Al-Fatimi, Martina Wurster, Gudrun Schroder, Ulrike Lindequist (2007) Antioxidant, antimicrobial and cytotoxic activities of selected medicinal plants from Yemen. J. Ethnopharmacol. 111, 657-666.

38. Moure A, Cruz J, Franco D, Dominguez J, Sineiro J and Dominguez $H$ (2001) Natural antioxidants from residual sources. Food Chem. 72, 145-171.

39. Murthy EN, Sudhakar Reddy C, Reddy KN and Raju VS (2008) Ethnomedicinal observations from the MahaMutharam and Yamanpally tribal villages of Karimangar, East forest division of Andhra Pradesh, India .Ethnobotanical Leaflets, 12, 513-51.

40. Nadkarni KM (1976) Indian Meteria Medica, $3^{\text {rd }}$ Edn. Popular Prakhasan, Bombay, 1,165.

41. Nandgude TD, Bhojwani AP and Krishna Kinage (2007) Analgesic activity of various extracts of leaves of Azima tetracantha Lam. Int. J. Green Pharm. 1(1), 37-38.

42. Nathan CF and Hibbs Jr JB (1991) Role of nitric oxide synthesis in macrophage antimicrobial activity. Curr. Opin. Immunol. 3, 65-70.

43. Nowakowska $Z$ (2007) A review of anti-infective and anti-inflammatory chalcones. Eur. J. Med. Chem. 42,125137. B.S.

44. Ohkawa H, Ohishi N and Yagi K (1979) Assay of lipid peroxides in animal tissues by thio babituric acid reaction. Anal. Biochem. 95, 351.

45. Pacher $P$, Beckman JS and Liaudet $L$ (2007) Nitric oxide and peroxynitrite: In health and disease. Physiol. Rev. 87(1), 315-424.

46. Patricia I, Oteiza AG, Erlejman S, Verstraeten V, Keen $\mathrm{CL}$ and Fraga CS (2005) Flavonoid-membrane interactions: A protective role of flavonoids at the membrane surface. Clinl. Develop. Immunol. 12, 23-25.

47. Pervaiz S and Clement M (2007) Superoxide anion: oncogenic reactive oxygen species? Int. J. Biochem. Cell Biol. 39, 1297-1304.

48. Pong K (2003) Oxidative stress in neurodegenerative diseases: therapeutic implications for superoxide dismutase mimetics. Exp. Opin. Biol. Therapy. 3,127-139.

49. Prieto P, Pineda $M$ and Agulilar M (1999) Spectrophotometric quantification of antioxidant capacity through the formation of phosphomolybdenum complex: specific application of Vit E. Anal. Biochem. 269, 337-341.
Vol. 3 No. 5 (May 2010)

ISSN: 0974- 6846

50. Ragupathy S, Newmaster G Steven, Maruthakkutti M, Velusamy B and UI-Huda MM (2008) Consensus of the 'Malasars' traditional aboriginal knowledge of medicinal plants in the Velliangiri holy hills. Ind. J. Ethnobiol. Ethnomed. 4, 8.

51. Rajesh Manian , Nagarajan Anusuya , Perumal Siddhuraju and Sellamuthu Manian (2008) The antioxidant activity and free radical scavenging potential of two different solvent extracts of Camellia sinensis (L.) O. Kuntz, Ficus bengalensis L. and Ficus racemosa L. Food Chem. 107, 1000-1007.

52. Rall GJH, Smalberger TM, De Waal HL and Arndt RR (1967) Dimeric piperidine alkaloids from Azima tetracantha. Tetrahedron Letts. 3465-3469.

53. Rao VE and Prasada Rao PRS (1978) Occurrence of triterpenoids in Azima tetracantha. Curr. Sci. 47, 857.

54. Robak J and Marcinkiewiez E (1995) Scavenging of reactive oxygen species as the mechanism of drug action. Pol. J. Pharmacol. 47, 89-98.

55. Ruch RT, Cheng SJ and Klawnig E (1989) Prevention of cytotoxicity and inhibition of intercellular communication by auto oxidant catechins isolated from Chinese green tea. Carcinogenesis, 10, 1003-1008.

56. Sandhya B, Manoharan S, Sirisha Lavanya G and Ch. Ratna Manmohan (2010) Lipid peroxidation and antioxidant status in prostate cancer patients. Indian J.Sci.Technol. 3 (1), 83-86. Domain site: http://www.indjst.org.

57. Schanderl S (1970) Methods in food analysis. Academic press New York, p70.

58. Shahidi F, Liyana-Pathirana CM and Wall DS (2006) Antioxidant activity of white and black sesame seeds and their hull fractions. Food Chem. 99, 478-483.

59. Siva N, Ganesan N, Banumathy and Muthuchelian (2008) Antifungal effect of leaf extract of some medicinal plants against Fusarium oxysporum causing wilt disease of Solanum melogena L .Ethnobotanical Leaflets.12, 156163.

60. Vetrivel Rajan, Shanmugavalli N, Greety Sunitha C and Umashankar V (2009) Hepatoprotective effects of Cassia tora on $\mathrm{CCl}_{4}$ induced liver damage in albino rats. Indian J.Sci.Technol. 2 (3), 41-44. Domain site: http://www.indjst.org.

61. Vikneshwaran D, Viji M and Raja Lakshmi K (2008) A survey of the Ethnomedicinal flora of the Sirumalai hills, Dindugul District, India. Ethnobotanical Leaflets, 12, 94853.

62. Williams UV and Nagarajan S (1988) Isorhamnetin-3Orutinoside from leaves of Azima tetracantha Lam. Ind. J. Chem. 27, 387.
Research article

CIndian Society for Education and Environment (iSee)
"Herbal antioxidant" http://www.indjst.org
Thendral et al. Indian J.Sci.Technol. 